\title{
Marketing Strategies in Equity Crowdfunding: A Comparative Study of Italian Platforms
}

\author{
Ciro Troise ${ }^{1}$ \\ ${ }^{1}$ Department of Management, Università degli Studi della Campania “Luigi Vanvitelli”, Capua (CE), Italy \\ Correspondence: Ciro Troise, Department of Management, Università degli Studi della Campania "Luigi \\ Vanvitelli”, Corso Gran Priorato di Malta - 81043 Capua (CE), Italy. E-mail: ciro.troise@unicampania.it
}

Received: August 11, 2019 Accepted: September 7, $2019 \quad$ Online Published: September 29, 2019

doi:10.5539/ijms.v11n4p16 URL: https://doi.org/10.5539/ijms.v11n4p16

\begin{abstract}
This paper explores equity crowdfunding platforms from a marketing perspective. The present exploratory study attempts to make a double contribution to the current literature on equity crowdfunding. Firstly, it analyzes the marketing strategies of the platforms by focusing on the well-known 4Ps marketing mix framework, i.e. product, price, promotion and placement. Each dimension presents three types of categories. Second, the study investigates the marketing strategies of both large platforms and small platforms, then the differences between these two types of platforms are examined in terms of campaigns' outcomes, i.e. funding collected (in \%), funding amount (in $€$ ) and number of investors. Platforms adopt a standardization strategy for pricing and placement, while a differentiation strategy is mainly adopted for promotion and products. Large platforms offer a wider range of services (in particular ongoing campaign services and post-campaign services) and promotional activities (in particular leverage many communication channels). The analyses disclose significant statistically differences between these two types of platforms. Projects posted on large platforms are more likely to get higher campaigns' outcomes. In literature, little is known about marketing strategies in equity crowdfunding platforms, thus this study tries to fill this gap. The paper is the first to analyze the 4Ps of platforms and to conduct a comparative empirical study to determine the differences of campaigns' outcomes between large and small platforms. The Italian context represents a significant case of developed country in theme of equity crowdfunding. The results are useful for platform managers, entrepreneurs, investors and authorities.
\end{abstract}

Keywords: crowdfunding, equity model, marketing strategies, 4Ps, marketing mix, online platforms, two-sided platforms, investors, entrepreneurs

\section{Introduction}

Crowdfunding is one of the new actors that have entered the entrepreneurial finance arena (Block et al., 2018) and it has experienced a rapid expansion after the 2008-2009 global financial crisis (De Buysere et al., 2012; Yamen \& Golfeder, 2015). Among the crowdfunding models, equity crowdfunding (ECF hereafter) is "a form of financing in which entrepreneurs make an open call to sell a specified amount of equity or bond-like shares in a company on the Internet, hoping to attract a large group of investors" (Ahlers et al., 2015, p. 955).

Some scholars have argued that ECF is a new tool in start-up financing able to fill the funding gap for the initial stages (Ley \& Weaven, 2011; Macht \& Weatherson, 2014; Manchanda \& Muralidharan, 2014). Over the years, the ECF phenomenon has assumed considerable dimensions and its economic impact is significant. In fact, the ECF market is constantly growing: 400 million dollars in 2013, 1.1 billion dollars in 2014, 2.56 billion dollars in 2015 and over 4 billion dollars in 2016 (Massolution, 2016).

In this scenario, crowdfunding platforms are spreading worldwide. These platforms are a typical example of two-sided platforms (Ryu, 2018) that connect entrepreneurs (or creators) to small investors, i.e. the crowd (Harrison, 2013; Belleflamme et al., 2014; Bruton et al., 2015; Cumming et al., 2015; Salomon, 2016). Since the majority of ECF platforms operate with the AON (all or nothing) model, where companies set a funding goal below which they do not keep any of the pledged funds (Cumming et al., 2014), the success of campaigns is a critical aspect. In this vein, many scholars examined several factors - related to the characteristics of companies and campaigns_-which affect projects' success (e.g., Ahlers et al., 2015; Vismara, 2016), while only a limited number of studies focused on the characteristics of the platforms (e.g., Cumming \& Zhang, 2018; Rossi \& Vismara, 2018). 
In the current literature, some scholars concur that crowdfunding is a useful marketing tool (Hu et al., 2015; Sayedi \& Baghaie, 2017; Di Pietro et al., 2018), but little is known about the marketing strategies of the platforms. Marketing, in particular marketing mix, is a crucial element for any type of business and can help to achieve better competitive positions (Grönroos, 1994; Goi, 2009). The growth of web has a significant impact on customer and business market behaviors (Sharma \& Sheth, 2004), and it presents many opportunities for several players. Marketing has a fundamental importance also for platforms, but this has been relatively neglected by the literature on crowdfunding and it remains a very little investigated topic.

The present paper studies ECF from a marketing perspective and tries to address this gap by investigating two research questions. Firstly, this study examines the marketing strategies of ECF platforms by leveraging the well-known 4Ps marketing mix framework (RQ1). Second, the paper analyzes the differences between large platforms (LPs hereafter) and small platforms (SPs hereafter), in terms of ECF campaigns' outcomes (RQ2). Thus, this research not only explores the choices of ECF platforms in terms of products, prices, promotion and placement, but also compares LPs and SPs, two types of platforms - in terms of size (i.e., the number of project posted) - that present different marketing strategies. In doing this, six Italian ECF platforms (3LPs and 3SPs) are examined and a univariate analysis is conducted in order to investigate whether and how LPs differ from SPs.

To the best of author's knowledge, this paper is the first to analyze the 4Ps of ECF platforms and to conduct a comparative empirical study to determine the differences of campaigns' outcomes between LPs and SPs. ECF campaigns' outcomes are uncertain and difficult to predict, this work seeks to add new knowledge in the ECF research stream and explores two aspects not yet discussed in the literature, i.e., the 4Ps and LPs vs. SPs.

This article is structured as follows: Section 2 presents a review of literature; Section 3 presents the research design including the research context, data and marketing strategies; Section 4 presents the results while the last section concludes the paper.

\section{Literature Review}

The literature on crowdfunding is mainly based on the reward model, but recently there has been a significant development of the ECF research stream. Mochkabadi and Volkmann (2018) conducted a systematic literature review exclusively on ECF. The scholars examined 113 journal contributions and provided a classification based on 5 perspectives: capital market, entrepreneur, institutional, investor and platform. Within the platform perspective (scholars identified 14 papers), most publications focus on the design of ECF platforms (e.g., Chen et al., 2016; Grundy \& Ohmer, 2016; Salomon, 2016; Löher, 2017).

Crowdfunding platforms act as intermediaries between capital-seeking entrepreneurs and investors (Harrison, 2013; Bruton et al., 2015; Cumming et al., 2015; Salomon, 2016; Löher, 2017). These platforms are a type of multisided platforms (Ryu, 2018) and can also be interpreted as community-driven platforms. Platforms which operate in many countries allow entrepreneurs to describe their funding needs and tap into the wisdom of crowds (Surowiecki, 2005; Mollick \& Nanda, 2015; Polzin et al., 2018). The value of these platforms grows attracting more users, the so-called network effect (Katz \& Shapiro, 1985; Osterwalder \& Pigneur, 2010), and it is based on the quantity and variety of agents on the sides (direct and indirect network effects), that refers to the theory of network externalities (Rochet \& Tirole, 2006). Generally speaking, the size of one side influences their ability to draw users on the other side (Evans, 2003; Wright, 2004; Bakos \& Katsamakas, 2008). The development of ECF platforms attract both entrepreneurs and investors. The latter prefer larger platforms that offer a wider range of campaigns, allowing greater choice for them. This increased number of investors should also lead to an increase number of entrepreneurs launching campaigns (Tomczak \& Brem, 2013). In many countries (e.g., France), larger platforms are better able to support the changes and the additional costs of compliance with new regulations, compared to smaller platforms (Kirby \& Worner, 2014). Also, in the present study, a distinction is made between LPs and SPs, as we will see in the following paragraph.

The first goal of crowdfunding is to obtain financial resources, but recent studies started to consider crowdfunding as a new marketing tool. Among the first studies to analyze crowdfunding from a marketing perspective is the paper by $\mathrm{Hu}$ et al. (2015). The scholars focused on crowdfunding's effects on product line design (in particular price and product). Sayedi and Baghaie (2017) explored the strategic aspects of using crowdfunding as a marketing tool. The scholars argued that "From a marketing perspective, crowdfunding can be used as a means of estimating the demand. Producers can use crowdfunding sites to perform market research virtually free of cost" (2017, p. 3). A recent study by Di Pietro et al. (2018), highlighted the key role of ECF as an open innovation mechanism. The scholars, by examining 60 startups that recur to ECF, found that the crowd acts as business ambassador and as a marketing channel. Thus, startups not only obtain an early validation of the product but also a concrete contribution to their growth through the exploitation of the investors' network. 
In the current literature, the paper by Rossi and Vismara (2018) is the first to provide cross-platform evidence in this field and to explore platforms' services, a typical parameter of the 4Ps, i.e. product. The scholars documented which services are offered to proponents (before, during, and after the campaigns) and highlighted that a higher number of post-campaign services offered by the platforms increase the annual number of successful campaigns.

Currently, research about ECF platforms' services remains very limited and none of the previous cited studies have explored the different marketing strategies of platforms. Due to its newness, the contribution of existing research towards explaining marketing strategies in the ECF campaigns' outcomes remains small.

\section{Research Design}

\subsection{Research Context}

In the post-crisis scenario, several governments worldwide developed specific regulations for ECF (Gabison, 2015). In recent years, ECF has experienced significant growth especially in Europe (Vismara, 2016). Important examples of countries that have developed specific regulations are Italy, France, Germany and the UK (Rossi \& Vismara, 2018).

This paper focuses on Italy, a representative case of a developed country in term of ECF regulations. The Italian context represents a vibrant case in the ECF field and the focus on this country is due to many reasons. Firstly, Italy became the first country in Europe to define a specific regulation (Decreto Legge n. 179/2012 or Decreto Crescita 2.0) and the Italian authority Consob (Commissione Nazionale per le Società e la Borsa) started maintaining a specific national registry of ECF platforms.

Second, the Italian ECF market is growing in numbers and there are increasing success rates of the campaigns (Politecnico of Milan, 2019). Figure 1 shows the positive trend of the funding collected over the years: $€ 1.31$ millions in $2014, € 1.77$ milions in $2015, € 4.28$ millions in 2016, $€ 11.65$ millions in 2017 and finally $€ 36.39$ millions in 2018. Volumes are growing considerably every year and the total capital raised (period 2014-2018) is over $€ 55$ millions.

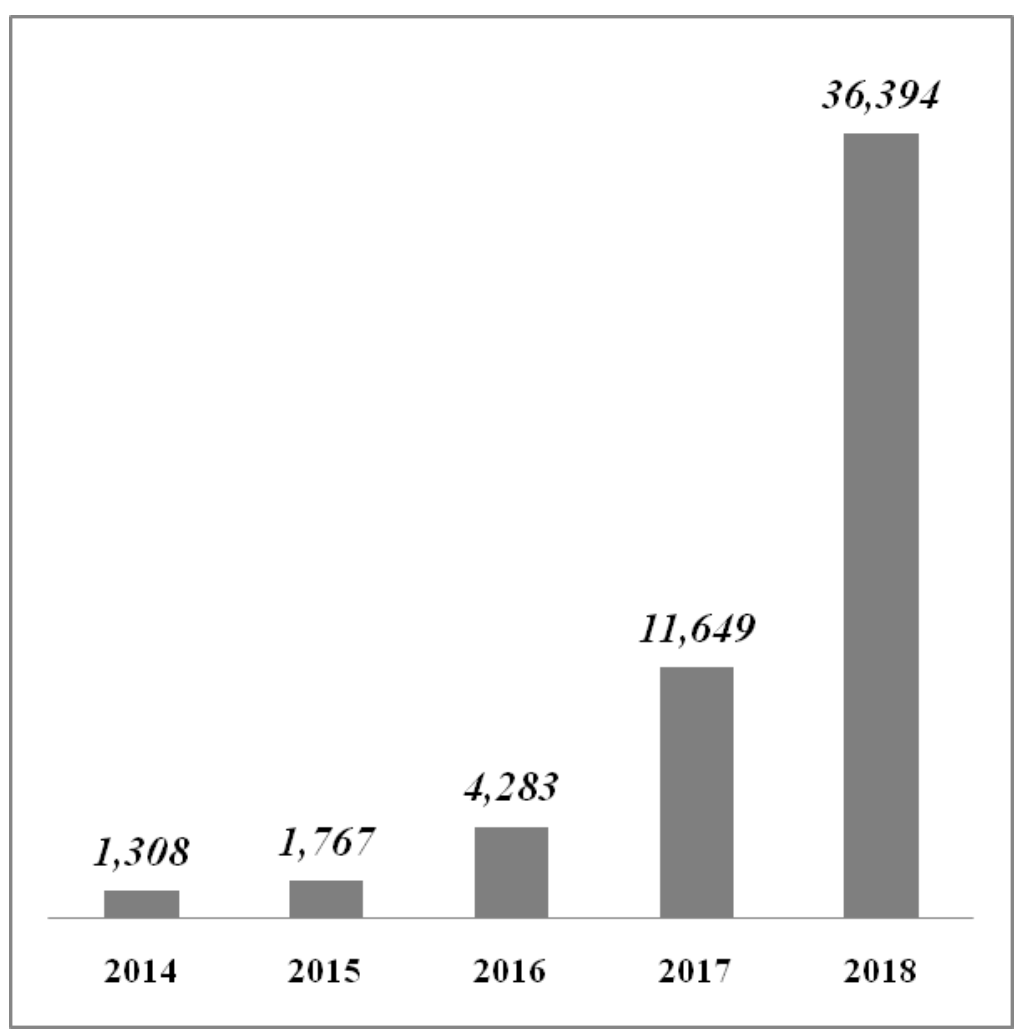

Figure 1. ECF volumes in Italy: total capital raised (2014-2018) in millions of euros $(€)$

Source: self-elaboration on "Politecnico of Milan" data (2019). 
Figures 2 shows the positive trend of campaigns' success rate over the years: $40 \%$ in $2014,43.75 \%$ in 2015 , $54.54 \%$ in $2016,68.91 \%$ in 2017 and $80.41 \%$ in 2018 .

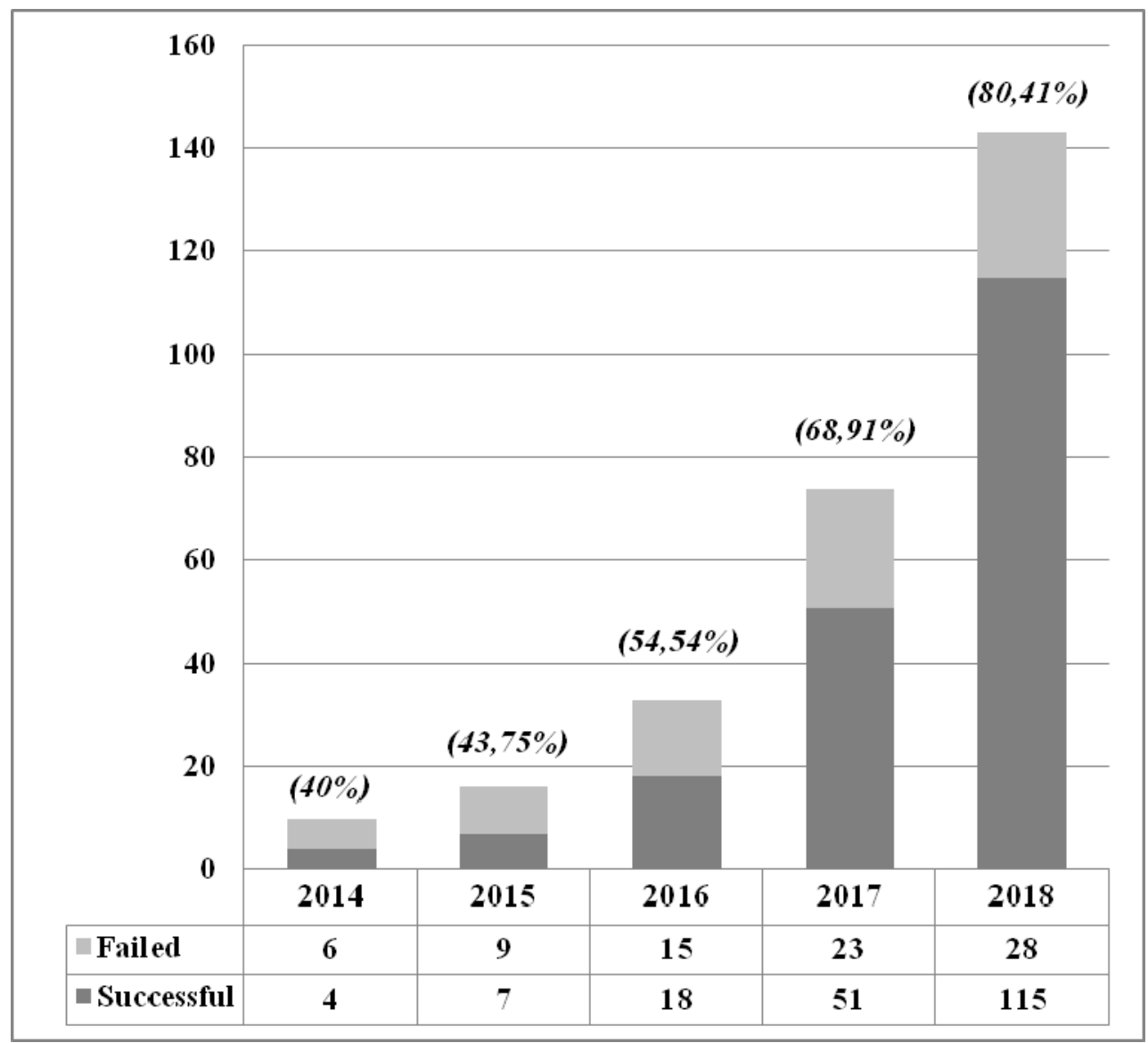

Figure 2. Success rate (in \%) of ECF campaigns (2014-2018)

Source: self-elaboration on "Politecnico of Milan" data (2019).

Note: success rate in parentheses.

Third, the main part of the Italian business structure is characterised by SMEs and start ups. These ventures, which makes up most of the production base of the country, are the main target of the ECF mechanism.

Fourth, Italy is part of the EU and the EEA (European Economic Area), and its economy is a typical example of open Western economy. Considering the main development indicators of the countries (e.g., World Bank development indictors), Italy has high levels similar to the main European countries. Among them, for example, it is in the top 20 "Internet Users by Country of the World" (especially considering the last three years), with numbers close to those in the UK and France.

Fifth, in Italy ECF platforms are rapidly evolving and are implementing new services. They are receptive to innovations and are predisposed to the implementation of useful products/services for their users. The development of the platforms is realized through a series of features and new services offered. Specific characteristics allow platforms to attract both investors and entrepreneurs. An increasing number of investors is vital for platforms but above all for companies that - thanks to them - are able to achieve their goals. In addition to the traditional and basic sections, several platforms present a higher number of spaces and advanced services (e.g., links to social networks, direct contact with funders through comments, specific sections of questions and answers, updates, webminar, consultation by external firms for a first assessment of the project's potential interest or a technical feasibility examination of the initiative).

Finally, Italy is often mentioned in various crowdfunding studies, especially on ECF (e.g., Rossi \& Vismara, 2018) being considered of absolute international interest. ECF in Italy is a vibrant issue of great interest, 
regulation is constantly evolving (Note 1) and significant regulatory responses to risks have been introduced, such as the participation of qualified investors (who must subscribe at least $5 \%$ of the offer), the request to the platforms to conduct due diligence, a review of risk warnings, verification of requirements (e.g., integrity and professionalism), rules of conduct and obligations (information on investments and offers, protection and confidentiality). Policy makers are vigilant in implementing and improving the fundraising mechanism and its use (e.g., tax benefits). Italy presents a growing ecosystem rich of newness related to ECF. Thus, the Italian context can offer potential future research opportunities thanks to its dynamism and the growth of the sector. Some of the findings in the Italian context can then be applied to other countries.

\subsection{Data Collection and Sample}

Data were collected mainly from official ECF platform websites, but this research relied also on the integration of other data sources, such as social networks, press, blogs and official business register databases. ECF platforms and online campaigns' spaces were particularly useful for information on marketing strategies and ECF outcomes. This paper analyzes six Italian ECF platforms since their origin to June 2018: three LPs and three SPs. The LPs are CrowdFundMe (42 campaigns), Mamacrowd (31 campaigns) and StarsUp (30 campaigns), while the SPs are BacktoWork24 (formerly Equinvest; Note 2) (11 campaigns), Muumlab (4 campaigns), Nextequity (5 campaigns).

In the crowdfunding context it is common to consider platforms with a high number of projects as large (Kirby $\&$ Worner, 2014). The population of initiatives launched on online portals is a measure of the platform size. Few scholars (e.g., Chen et al., 2016) have also considered the number of community members as an additional variable for platform size. This study considers a platform as LPs if it has launched at least 30 projects $(\geq 30)$. The analyses of SPs highlighted that these platforms posted less than 12 projects $(\leq 11)$. Many scholars used more than one platform for their studies (Vismara, 2016; Hornuf \& Schmitt, 2018; Hornuf \& Schwienbacher, 2018). Some platforms are more attractive than others. For example, Vismara (2016) explored how the initiatives launched on the portal Seedrs attracted more investors and funds than did those on the platform Crowdcube.

Data collection spanned July 2014 to June 2018 and the final sample is composed of 123 campaigns: 103 projects posted on LPs and 20 on SPs. As for ECF campaigns' outcomes, this study considers the three most commonly used variables in literature: funding collected (in \%), funding amount (in $€$ ) and the number of investors (Ahlers et al., 2015; Ralcheva \& Roosenboom, 2016; Lukkarinen et al., 2016; Vismara, 2016, 2018; Block et al., 2018; Troise, 2019). These three well known parameters are proxies of success and explain ECF performance. In this study the main characteristics of the campaigns and of the companies (Ahlers et al., 2015; Vismara, 2016; Vulkan et al., 2016; Hornuf \& Schwienbacher, 2018; Troise, 2019) were also analyzed through typical control variables: target capital (in $€$ ), equity offered (in \%), team size (including founders), years, service industry (sector type), big city, start up size (company type). Furthermore, three typical parameters of innovative start ups and SMEs in Italy are included in the analyses: R\&D expenditures, qualified team members and youth prevalence. Most of the data are present on ECF platforms, especially for campaigns's outcomes, while some data about control variables were collected through the business register of start ups or SMEs (e.g., R\&D, qualified team, youth prevalence).

\subsection{ECF Platforms and 4Ps}

The concept of 4Ps is a staple of the marketing mix (Goi, 2009), although criticized by some scholars (e.g., Möller, 2006; Popovic, 2006), and it includes: products, prices, promotion and placement (McCarthy, 1960, 1964). The 4Ps are a means of translating marketing planning into practice (Bennett, 1997). The choices of marketing strategies identify the platform managers' decision-making process. These managers make their strategy decisions based on customer's needs. In the ECF case there are two main parties: companies that launch online calls in order to collect funds and investors that commit financial resources in order to support projects.

ECF platforms operate in a competitive market and new platforms are created every year, thus marketing strategies are of fundamental importance. Marketing mix is a strategic lever to add value to platforms' competitiveness in a growing market (although it is populated by platforms authorized by Consob). The main business model of Italian ECF platforms is the AON model, thus companies obtain the funds only if they reach the $100 \%$ of their funding goal. Since the success of ECF campaigns is vital for platforms, they must increase their efforts. This implies that platforms should offer large and high-quality services, competitive pricing policies, important and specific promotional activities, wide placement.

In the ECF context, product is one of the most important elements to consider and it could improve platforms' competitiveness. The number and the quality of the services are strategic elements for platforms. Following the paper by Cumming and Zhang (2018), Rossi and Vismara (2018) identified some key services. The scholars 
created three categories:

- Pre-launch services, i.e., the sum of the pre-launch services offered by the platform during the campaign's preparation phase (crowdsourcing, business planning, financial analysis, pitching and communication, promotion services, technical advisory, strategic guidance);

- Ongoing campaign services, i.e., the sum of the ongoing campaign services offered by the platform during the campaign's funding (angel led platform, institutional investor privilege, interaction, private launch)

- Post-campaign services, i.e., the sum of the post-launch services offered by the platform once the campaign has been closed successfully (advisory for further funding, exit assistance, general assistance, periodical updates, second market).

Also, the present study embraces this classification and considers these three typologies of services (Table 1).

Pricing is a crucial factor for the survival and the growth of platforms. In the crowdfunding literature, pricing is often analyzed in the price discriminate policies between two groups of consumers (Belleflamme et al., 2014), i.e. backers (they pre-purchase the products/services) and regular consumers (they wait until the product reaches the market to purchase it). Other studies (e.g., Agrawal et al., 2014) highlighted the lower cost of capital that crowdfunding entails. In this research stream there is a lack of studies that specifically analyzed platforms' pricing policies. ECF Platforms that operate with the AON model obtain a fee only in case of successful campaigns. There are no costs for investors, but the costs are only for companies. The fee is in $\%$ on the amount of capital raised at the end of campaigns, but some platforms apply publishing costs to companies. As for services, they are sold at different prices based on the various types. In sum, platforms show three categories of pricing (Table 1): fee (in \%) related to the funding amount collected, publication fee and the cost for services offered.

Promotion is one of the most important marketing activities. Through specific and effective promotional activities, platforms can achieve competitive advantages. The virtual and online context of platforms is a challenging environment for the players involved, i.e. entrepreneurs and the crowd. The widespread use of the Internet and social media offers many opportunities for platforms (Sharma \& Sheth, 2004; Mokhtar, 2015). Communication is changing over the years, in fact digital technologies and social networks (Mollick, 2014; Zheng et al., 2014) are replacing the traditional word of mouth (Berger \& Milkman, 2012; Berger, 2014). In particular personal social networks (e.g., Facebook, LinkedIn, etc.) play a key role in the crowdfunding context and are the most used by the stakeholders involved (Colombo et al., 2015; Vismara, 2016). Other two promotional activities are storytelling (Manning \& Bejarano, 2016) and advertising or sponsorhip (Carvajal et al., 2012; Qiu, 2013). Platform managers, in fact, usually manage promotion through successful stories and through ad hoc advertising (online and not) or by sponsoring strategic events (e.g., business plan competitions or incubators). Table 1 shows the three main platforms' promotional activities, i.e., social networks, storytelling and press, advertising and sponsorship. In literature, there are many contributions that focused on the role of crowdfunding as a promotion tool (e.g., Belleflamme et al., 2014), while the promotion is less investigated about the platforms.

Finally, also placement is an important aspect that platform managers should consider in their marketing strategies. Distribution policies can be a significant competitive advantage for ECF platforms. Many platforms target their customers (both entrepreneurs and investors) far and wide. It is important to underline that the current era is characterized by the advent of the digital and the large use of social media (Lamberton \& Stephen, 2016), thus online methods or tools could allow platforms to reach a high number of users and support low costs. Placement is the set of activities necessary to bring a specific product or service to the final consumer. In the virtual context of ECF platforms, an online two-sided market (Albuquerque et al., 2012; Ryu, 2018), also placement channels are mainly online. Online distribution of products or services via the Internet has added to traditional distribution systems. Both the Internet and the mobile influence the market and the 4Ps strategies (Albuquerque et al., 2012; Andrews et al., 2015). In this scenario, placement is mainly managed online and the services are distributed through the web. The adoption of Internet extends the placement activities (Mokhtar, 2015; Hobbs et al., 2016) and can intercept and involve several types of consumers. Both online activities (Albuquerque et al., 2012) and mobile activities (Andrews et al., 2015) are useful driver of marketing efforts. Nowadays digital marketing represents a significant opportunity for the future (Lamberton \& Stephen, 2016). A growing number of placement activities take place in the virtual domain rather than in the real one (Yamin \& Sinkovics, 2006; Mathews \& Healy, 2008). Well known examples of the main strategies of product placement are mass media (Galician, 2004) and marketing media (Karniouchina et al., 2018). It is possible to identify two main types of placement channels: direct distribution and indirect distribution (John \& Weitz, 1988; Kiang et al., 
2000; Russel \& Belch, 2005; Eggert et al., 2012). As for indirect distribution, a commonly used practices of placement is the selling of services through intermediaries (Russel \& Belch, 2005). Several platforms, in fact, recur to different types of intermediaries in order to reach different targets of consumers. Instead, direct distribution is a "direct-to-consumer" model and the platforms sell their services directly to the end consumers (John \& Weitz, 1988; Kiang et al., 2000; Eggert et al., 2012). There are two types of direct distribution: B2C (business-to-consumer), between the platforms and the final consumers (entrepreneurs and investors), and B2B (business-to-business), between the platforms and the final business user (e.g., other services' companies, financial players, etc.) (Tamilia et al., 2002; Teo, 2005; Merrilees \& Fenech, 2007; Halimi et al., 2011; Hadjikhani \& LaPlaca, 2013).

Table 1 summarizes the 4Ps of the ECF platforms, three categories for each dimension.

Table 1. ECF Platforms: classification of the 4Ps

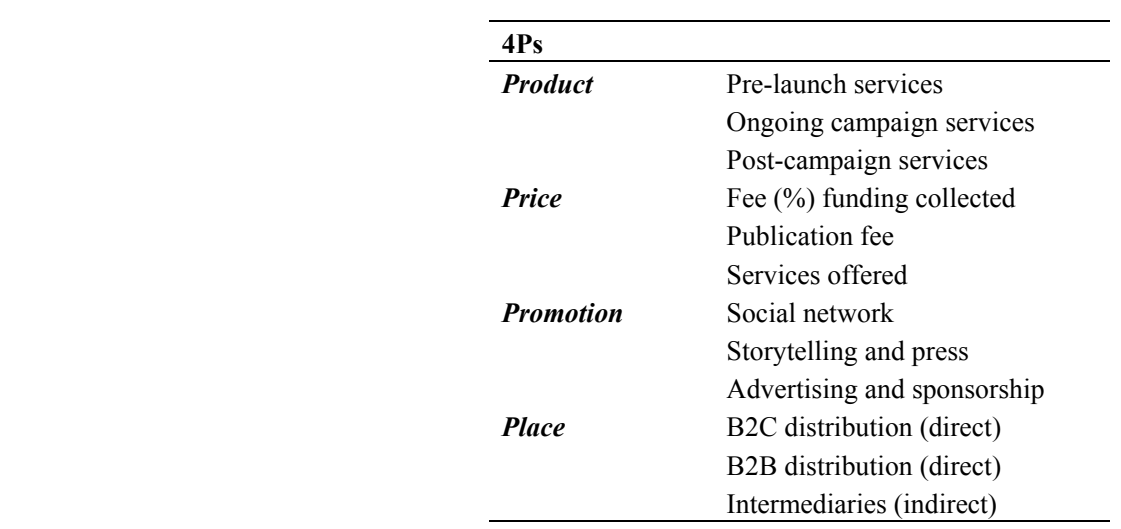

Source: author's personal elaboration.

\section{Results}

\subsection{LPS and SPS: The 4PS}

Following the scheme in Table 1, the 4Ps were analyzed both for LPs and SPs. The single parameters were verified by several sources: ECF platforms' websites, platforms' social networks (in particular LinkedIn and Facebook), specific press, dedicated blogs and other reputable sources of the sector (e.g., information by Consob, ad hoc reports by important stakeholders like universities and well-known startup sites, such as Crunchbase or AngelList).

ECF platforms seem to adopt a differentiation strategy for promotion and products, while a standardization strategy is the most recurrent for pricing and placement.

As for pricing, both LPs and SPs require costs in term of fee in percentage on the collected funding amount. This fee ranges between $2 \%$ and $10 \%$, thus companies have to pay an average fee of about $6 \%$ in case of successful campaigns. Platforms standardise services' pricing, in fact they do not differ significantly between LPs and SPs, while there seems to be only one SPs (i.e. Muumlb) that applies publishing costs to companies (a publication fee of $€ 700)$.

Also for placement, platforms tend to standardize their strategies. LPs and SPs recur both to direct (B2B and B2C) policies, i.e. a direct distribution by contacting the parties, and indirect policies, i.e. resort to specific intermediaries.

As for products, analysis of the platforms' services shows that LPs and SPs offer several types of services and these services differ. Services are offered according to a differentiation strategy. The pre-launch services are similar in LPs and SPs (e.g., pitching and technical advisory), and some platforms (the three LPs and Nextequity, among the SPs) resort to a specific technical feasibility by external evaluation. LPs tend to offer a wider range of ongoing campaign services and post-campaign services, while SPs seem to offer few services or do not offer certain types of services. Among the ongoing campaign services, LPs provide a tailored space for the interaction between the two parties (i.e., entrepreneurs and investors), such as forum, chat or specific section dedicated to comments and updates. The platform Mamacrowd provides an ad hoc service of webminar, a useful tool to involve the crowd and favor a direct interaction of investors. Post-campaign services, in particular periodical updates and news post campaigns, are mainly offered by LPs (among the SPs, only BacktoWork24 seems to 
provide this service). CrowdFundMe offers a specific service related to the alternative regime for the registration of shares is an ad hoc regime (provided for by TUF-"Testo Unico della Finanza").

Finally, as for promotion, there are some differences between LPs and SPs. The main social networks (e.g., Facebook, LinkedIn, Instagram, Twitter and YouTube) are used by all platforms, but LPs resort also to other specific tools. For example, Mamacrowd uses the above cited webminar format and also Vimeo, a well-known web's community of creators that offers tools for hosting, sharing, and streaming videos. Instead, CrowdFundMe is the first platform in Italy to resort to the opt-in process.

Several platforms (e.g., Mamacrowd and Nextequity) recently started to introduce specific sections dedicated to best practices, i.e., successful stories. Finally, advertising and sponsorships are two parameters that especially LPs leverage. For example, CrowdFundMe cooperates with renowned press agencies and exploits the promotion through newspapers (Il Sole 24 Ore, Milano Finanza, Corriere Innovazione, etc.). Furthermore, this platform performs roadshows and joins specific events. Finally, sponsorships is a key activities and some platforms (e.g., Mamacrowd) are present in strategic events such as business plan competitions, incubator/accelerator programs and so on.

\subsection{Descriptive Statistics}

Table 2 and Table 3 provide descriptive statistics respectively of the ECF campaigns' outcomes and characteristics of LPs (Table 2) and SPs (Table 3). The number of observations in the first table is 103, while the second table counts 20 observations.

As for LPs campaigns' outcomes, Table 2 shows that: the average percentage of funding collected is $174.28 \%$ and ranges from $0 \%$ to $950 \%$; the collected funding amount is on average $€ 204,255$ and it ranges from 0 to $€$ $1,242,000$; investors are on average 70 , this number ranges from 0 to 358 .

Table 2. Large Platforms (LPs)

\begin{tabular}{lllllll}
\hline & & Obs & Mean & Std. Dev. & Min & Max \\
\hline Outcomes & Funding Collected (\%) & 103 & 174.28 & 163.17 & 0 & 950 \\
& Funding Amount (in $€$ ) & 103 & 204,255 & 215,755 & 0 & $1,242,000$ \\
& Number of Investors & 103 & 70.04 & 71.14 & 0 & 358 \\
\hline Characteristics & Target Capital (in $€$ ) & 103 & 143,902 & 106,639 & 45,000 & 710,000 \\
& Equity Offered (\%) & 103 & 9.86 & 9.35 & 0.10 & 50 \\
& Team size & 103 & 6.59 & 3.94 & 2 & 25 \\
& Years & 103 & 2.46 & 2.63 & 0 & 21 \\
& Service Industry & 103 & 0.75 & 0.44 & 0 & 1 \\
& Big City & 103 & 0.58 & 0.50 & 0 & 1 \\
& Start up Size & 103 & 0.87 & 0.33 & 0 & 1 \\
& R\&D & 103 & 0.61 & 0.49 & 0 & 1 \\
& Qualified Team & 103 & 0.37 & 0.48 & 0 & 1 \\
& Youth Prevalence & 103 & 0.32 & 0.58 & 0 & 1 \\
\hline
\end{tabular}

Notes: This table shows the mean, standard deviation (Std.Dev.), minimum value (Min), and maximum value (Max) for all variables. The sample covers 103 projects launched on the three LPs.

Table 3 reports the SPs campaigns' outcomes: the average percentage of funding collected is $91.61 \%$ and ranges from $0 \%$ to $246 \%$; the collected funding amount is on average $€ 163,649$ and it ranges from 0 to $€ 1,001,024$; investors are on average 16, this number ranges from 0 to 56 . 
Table 3. Small Platforms (SPs)

\begin{tabular}{lllllll}
\hline & & Obs & Mean & Std. Dev. & Min & Max \\
\hline Outcomes & Funding Collected (\%) & 20 & 91.61 & 76.48 & 0 & 246 \\
& Funding Amount (in $€$ ) & 20 & 163,649 & 238,342 & 0 & $1,001,024$ \\
& No. Crowdfunders & 20 & 15.65 & 16.74 & 0 & 56 \\
\hline Characteristics & Target Capital (in $€$ ) & 20 & 208,853 & 188,057 & 50,000 & 700,017 \\
& Equity Offered (\%) & 20 & 12.78 & 10.34 & 1.79 & 35.26 \\
& Team size & 20 & 6.25 & 3.37 & 2 & 16 \\
& Years & 20 & 4.25 & 5.08 & 0 & 23 \\
& Service Industry & 20 & 0.80 & 0.41 & 0 & 1 \\
& Big City & 20 & 0.60 & 0.50 & 0 & 1 \\
& Start up Size & 20 & 0.85 & 0.36 & 0 & 1 \\
& R\&D & 20 & 0.90 & 0.31 & 0 & 1 \\
& Qualified Team & 20 & 0.45 & 0.51 & 0 & 1 \\
& Youth Prevalence & 20 & 0.20 & 0.41 & 0 & 1 \\
\hline
\end{tabular}

Notes: This table shows the mean, standard deviation (Std.Dev.), minimum value (Min), and maximum value (Max) for all variables. The sample covers 20 projects launched on the three SPs.

\subsection{Univariate Test}

The present research is conducted through a comparative study using objective data collected from six Italian platforms (3LPs and 3SPs). In this study, a univariate test is performed and Table 4 gives the results of the analysis. More precisely, Table 4 presents the difference in means between LPs and SPs.

This type of test is recurrent in the crowdfunding studies (e.g., Ahlers et al., 2015; Zheng et al., 2014) and is useful to compare different samples by testing their means. Through this univariate analysis, the present paper aims to explore whether and how LPs differ from SPs in terms of campaigns' outcomes and the other characteristics.

The test shows significant differences between the two types of platforms. Projects posted on LPs are more likely to reach the target capital and exceed $100 \%$, while the projects posted on SPs are less likely to reach the target capital and, in fact, they tend to present percentages of funding collected below $100 \%$ (the average value is 91.61\%). This is a significant issue considering that the platforms' model is AON and therefore the projects fail if they do not reach the target. LPs favor the overfunding of the projects (in means 174.28\%).

As for funding amount (in $€$ ) and the number of investors, the analysis discloses that LPs have higher values than SPs. Initiatives tend to collect superior funding amounts in LPs (in means $€ 204,255$; instead, on SPs it is $€$ 163,649 ) and to involve more investors (in means 70 ; instead, on SPs it is 16). These results are very important since the main goals of crowdfunding are to raise funds and accumulate a large number of backers.

As for the other characteristics, projects posted on SPs tend to set a higher target capital ( $€ 208,853$; instead, on LPs it is $€ 143,902)$ and to offer a larger percentage of equity $(12.78 \%$; instead, on LPs it is $9.86 \%)$. The other variables have very similar values and do not differ significantly.

Table 4. Univariate test: mean differences between LPs and SPs

\begin{tabular}{llllll}
\hline & & Big Platforms (mean) & Small Platforms (mean) & Difference test (in means) \\
\hline Outcomes & Funding Collected (\%) & 174.28 & 91.61 & 82.67 & $*$ \\
& Funding Amount (in $€$ ) & 204,255 & 163,649 & 40,606 & $*$ \\
& Number of Investors & 70.04 & 15.65 & 54.39 & $*$ \\
Characteristics & Target Capital (in $€$ ) & 143,902 & 208,853 & $-64,951$ & -2.92 \\
& Equity Offered (\%) & 9.86 & 12.78 & 0.34 & $*$ \\
& Team size & 6.59 & 6.25 & $-1,79$ & -0.05 \\
& Years & 2.46 & 4.25 & -0.02 & \\
& Service Industry & 0.75 & 0.80 & 0.02 & \\
& Big City & 0.58 & 0.60 & -0.29 & -0.08 \\
& Start up Size & 0.87 & 0.85 & 0.12 \\
\hline
\end{tabular}

Note: Significance level at $1 \%\left({ }^{* * *}\right), 5 \%\left({ }^{* *}\right)$, and $10 \%(*)$. 


\section{Discussion and Conclusions}

ECF is a new financing tool and we know very little about marketing strategies adopted by platforms. This research contributes to the nascent ECF literature and seeks to make a first few steps towards an understanding of marketing strategies in the ECF context by exploring LPs and SPs. In this study it is found that LPs differ from SPs in terms of campaigns' outcomes and the work adopts a marketing perspective.

Firstly, this paper focuses specifically on platforms' marketing strategies in terms of the well-known 4Ps, while the few previous studies explored only limited aspects, such as services. Specifically, this study describes the 4Ps (i.e., product, price, promotion and price) through twelve items, three for each cathegories. Platforms adopt a standardization strategy for pricing and placement, while a differentiation strategy is mainly adopted for promotion and products. Similar pre-launch services are offered by all platforms, while LPs offer a wider range of ongoing campaign services and post-campaign services than SPs. Also, in term of promotion, LPs disclose higher promotional activities and leverage a large number of communication channels (some novelties for example are webminar, Vimeo, opt-in process, road-shows and specific press), while social networks (Facebook, Instagram, LinkedIn, etc.) are commonly used also by SPs. The study provides evidence on the importance of marketing strategies for campaigns' outcomes. It is important for entrepreneurs the choice of platforms when they decide to launch their campaigns. Platforms that present vibrant and evolving marketing activities are more likely to satisfy the parties involved and to help entrepreneurs to obtain higher campaigns' outcomes.

Second, this study explores campaigns' outcomes and characteristics both in LPs and SPs, then a univariate test discloses significant differences between these two types of platforms. Campaigns' outcomes are statistically different for LPs and SPs. Projects posted on LPs are more likely to obtain higher campaigns' performance in term of funding collected (in \%), funding amount (in $€$ ) and number of investors. Also target capital and equity offered are different in LPs and SPs. In particular, projects posted on SPs present larger percentage of equity offered. Since SPs disclose a lower capability to reach the target capital (thus a project fails if the funding in percentage is less than $100 \%$ ), equity offered in large proportion seems to influence negatively the campaigns' outcomes and thus the success of campaigns. This result confirms the evidence of prior studies in the ECF field (e.g., Ahlers et al., 2015; Vismara, 2016; Troise, 2019). No significant differences were found between projects posted on LPs and SPs in term of other characteristics (team size, years, service industry, big city, start up size, $\mathrm{R} \& \mathrm{D}$, qualified team and youth prevalence).

Results deriving from this study, and in particular from the univariate test, drive to carry out further analyses. The scheme presented for the 4Ps offers the opportunity to explore the (single) parameters through specific variables in a more analytic quantitative model. A next study intends to carry out regression analyses in order to test the impact of the 4Ps attributes on ECF performance and it will analyze the 4Ps in a quantitative way. At this stage, a limitation of the study is that the comparison between LPs and SPs occurs in terms of campaigns' outcomes, while marketing strategies, i.e. the 4Ps, were not analyzed through a quantitative method. The 4Ps, in fact, have been described for both LPs and SPs by comparing each parameter. However, this study does not examine the specific impact of each "P" on campaigns' outcomes and does not offer a quantitative effect of the relationship between individual strategies and test results. In order to overcome this limitation, a subsequent study will examine the direct relationship between the 4Ps and campaigns outcomes, and also how (and to what extent) product, price, promotion and placement influence LPs and SPs performances.

This paper reveals new insights about ECF in Italy, a developed country in this field, but the findings could offer new opportunity of research in other countries. Hopefully, the present study could have implications for platform managers, entrepreneurs, investors and authorities. These actors aim at the success of the campaigns and this influences their decision-making process.

Marketing strategy is vital for ECF platforms, thus their managers should implement new marketing strategies and improve the services offered. Entrepreneurs should analyze platforms' strategies before making their choice and launch the campaign. In this vein, Rossi \& Vismara (2018) suggested that post-campaign services play a key role, in fact they increase the annual number of successful campaigns. Strategies, in particular services strategy, are significant also for investors that make their investment choices. Finally, authorities should support the growth of ECF tool and improve platforms' competitiveness (e.g., encouraging the use of post-campaign services).

\section{References}

Agrawal, A., Catalini, C., \& Goldfarb, A. (2014). Some Simple Economics of Crowdfunding. Innovation Policy and the Economy, 14(1), 63-97. https://doi.org/10.3386/w19133 
Ahlers, G. K., Cumming, D., Gunther, C., \& Schweizer, D. (2015). Signaling in Equity Crowdfunding. Entrepreneurship Theory and Practice, 39(4), 955-980. https://doi.org/10.1111/etap.12157

Albuquerque, P., Pavlidis, P., Chatow, U., Chen, K. Y., \& Jamal, Z. (2012). Evaluating Promotional Activities in an Online Two-Sided Market of User-Generated Content. Marketing Science, 31(3), 406-432. https://doi.org/10.1287/mksc.1110.0685

Andrews, M., Luo, X., Fang, Z., \& Ghose, A. (2015). Mobile Ad Effectiveness: Hyper-Contextual Targeting with Crowdedness. Marketing Science, 35(2), 218-233. https://doi.org/10.1287/mksc.2015.0905

Bakos, Y., \& Katsamakas, E. (2008). Design and Ownership of Two-Sided Networks: Implications for Internet Platforms. Journal of Management Information Systems, 25(2), 171-202. https://doi.org/10.2753/MIS0742-1222250208

Belleflamme, P., Lambert, T., \& Schwienbacher, A. (2014). Crowdfunding: tapping the right crowd. Journal of Business Venturing, 29(5), 585-609. https://doi.org/10.1016/j.jbusvent.2013.07.003

Bennett, A. (1997). The five Vs - a buyer's perspective of the marketing mix. Marketing Intelligence \& Planning, 15(3), 151-156. https://doi.org/10.1108/02634509710165957

Berger, J. (2014). Word-of-Mouth and Interpersonal Communication: A Review and Directions for Future Research. Journal of Consumer Psychology, 24(4), 586-607. https://doi.org/10.1016/j.jcps.2014.05.002

Berger, J., \& Milkman, K. L. (2012). What Makes Online Content Viral? Journal of Marketing Research, 49(2), 192-205. https://doi.org/10.1509/jmr.10.0353

Block, J. H., Hornuf, L., \& Moritz, A. (2018). Which updates during an equity crowdfunding campaign increase crowd participation? Small Business Economics, 50(1), 3-27. https://doi.org/10.1007/s11187-017-9876-4

Bruton, G., Khavul, S., Siegel, D., \& Wright, M. (2015). New financial alternatives in seeding entrepreneurship: microfinance, crowdfunding, and peer-to-peer innovations. Entrepreneurship Theory and Practice, 39(1), 9-26. https://doi.org/10.1111/etap.12143

Carvajal, M., García-Avilés J. A., \& González J. L. (2012). Crowdfunding and non-profit media. Journalism Practice, 6(5-6), 638-647. https://doi.org/10.1080/17512786.2012.667267

Chen, X., Zhou, L., \& Wan, D. (2016). Group social capital and lending outcomes in the financial credit market: An empirical study of online peer-to-peer lending. Electronic Commerce Research and Applications, 15(1), 1-13. https://doi.org/10.1016/j.elerap.2015.11.003

Colombo, M. G., Franzoni, C., \& Rossi-Lamastra, C. (2015). Internal social capital and the attraction of early contributions in crowdfunding. Entrepreneurship Theory and Practice, 39(1), 75-100. https://doi.org/10.1111/etap.12118

Cumming, D., Leboeuf, G., \& Schwienbacher, A. (2014). Crowdfunding Models: Keep-it-All vs. All-or-Nothing. SSRN Electronic Journal. https://doi.org/10.2139/ssrn.2447567

Cumming, D., Pandes, J. A., \& Robinson, M. J. (2015). The role of agents in private entrepreneurial finance. Entrepreneurship Theory and Practice, 39(2), 345-374. https://doi.org/10.1111/etap.12043

Cumming, D., \& Zhang, Y. (2018). Are Crowdfunding Platforms Active and Effective Intermediaries? (March 31, 2018). SSRN Electronic Journal. https://doi.org/10.2139/ssrn.2882026

De Buysere, K., Gajda, O., Kleverlaan, R., \& Marom, D. (2012). A Framework for European Crowdfunding. Resource Document, European Crowdfunding Network.

Di Pietro, F., Prencipe, A., \& Majchrzak, A. (2018). Crowd equity investors: an underutilized asset for open innovation in start-ups. California Management Review, 60(2), 43-70. https://doi.org/10.1177/0008125617738260

Eggert, A., Henseler, J., \& Hollmann, S. (2012). Who Owns the Customer? Disentangling Customer Loyalty in Indirect Distribution Channels. Journal of Supply Chain Management, 48(2), 75-92. https://doi.org/10.1111/j.1745-493X.2011.03260.x

Eisenmann, T., Parker, G., \& Van Alstyne, M. W. (2006). Strategies for Two-Sided Markets. Harvard Business Review, 84(10), 92-102. Retrieved from https://ssrn.com/abstract $=2409276$

Evans, D. S. (2003). Some Empirical Aspects of Multi-Sided Platform Industries. Review of Network Economics, 2(3), 191-209. https://doi.org/10.2202/1446-9022.1026 
Gabison, G. A. (2015). Equity crowdfunding: All regulated but not equal. DePaul Business and Commercial Law Journal, 13(3), 359-409. Retrieved from https://via.library.depaul.edu/bclj/vol13/iss3/2

Galician, M. L. (2004). Handbook of Product Placement in the Mass Media. New Strategies in Marketing Theory, Practice, Trends, and Ethics. New York: Routledge. https://doi.org/10.4324/9780203824702

Goi, C. L. (2009). A review of Marketing Mix: 4Ps or More? International Journal of Marketing Studies, 1(1), 2-14. https://doi.org/ 10.5539/ijms.v1n1p2.

Grönroos, C. (1994). From Marketing Mix to Relationship Marketing. Management Decision, 32(2), 4-20. https://doi.org/10.1108/00251749410054774

Grundy, D., \& Ohmer, C. (2016). German crowd-investing platforms: literature review and survey. Cogent Business \& Management, 3(1), 1-20. https://doi.org/10.1080/23311975.2016.1138849

Hadjikhani, A., \& LaPlaca, P. (2013). Development of B2B marketing theory. Industrial Marketing Management, 42(3), 294-305. https://doi.org/10.1016/j.indmarman.2013.03.011

Halimi, A. B., Chavosh, A., \& Choshalyc, S. H. (2011). The Influence of Relationship Marketing Tactics on Customer's Loyalty in B2C Relationship-The Role of Communication and Personalization. European Journal of Economics, Finance and Administrative Science, 31, 49-56. https://ssrn.com/abstract=1985284

Harrison, R. T. (2013). Crowdfunding and the revitalisation of the early stage risk capital market: catalyst or chimera? Venture Capital, 15(4), 283-287. https://doi.org/10.1080/13691066.2013.852331

Hobbs, J., Grigore, G., \& Molesworth, M. (2016). Success in the management of crowdfunding projects in the creative industries. Internet Research, 26(1), 146-166. https://doi.org/10.1108/IntR-08-2014-0202

Hornuf, L., Schmitt, M., \& Stenzhorn, E. (2018). Equity crowdfunding in Germany and the United Kingdom: Follow-up funding and firm failure. Corporate Governance: An International Review, 26(5), 331-354. https://doi.org/10.1111/corg. 12260

Hornuf, L., \& Schwienbacher, A. (2018). Market mechanisms and funding dynamics in equity crowdfunding. Journal of Corporate Finance, 50(C), 556-574. https://doi.org/10.1016/j.jcorpfin.2017.08.009

Hu, M., Li, X., \& Shi, M. (2015). Product and pricing decisions in crowdfunding. Marketing Science, 34(3), 331-345. https://doi.org/10.1287/mksc.2014.0900

John, G., \& Weitz, B. A. (1988). Forward Integration into Distribution: An Empirical Test of Transaction Cost Analysis. Journal of Law, Economics, \& Organization, 4(2), 337-355. https://doi.org/10.1093/oxfordjournals.jleo.a036955

Kappel, T. (2009). Ex Ante Crowdfunding and the Recording Industry: A Model for the U.S.. Loyola of Los Angeles Entertainment Law Review, 29(3), 375-385. Retrieved from https://digitalcommons.lmu.edu/elr/vol29/iss3/3.

Karniouchina, E. V., Uslay, C., \& Erenburg, G. (2018). Do Marketing Media Have Life Cycles? The Case of Product Placement in Movies. Journal of Marketing, 75(3), 27-48, https://doi.org/10.1509/jmkg.75.3.27

Katz, M. L., \& Shapiro, C. (1985). Network externalities, competition, and compatibility. The American Economic Review, 75(3), 424-440. Retrieved from https://www.jstor.org/stable/1814809

Kiang, M. Y., Raghu, T. S., \& Shang, K. H. M. (2000). Marketing on the Internet-who can benefit from an online marketing approach? Decision Support Systems, 27(4), 383-393. https://doi.org/10.1016/S0167-9236(99)00062-7

Kirby, E., \& Worner, S. (2014). Crowdfunding: an infant industry growing fast. Staff Working Paper, SWP 3/2014, IOSCO Research Department, 21 September.

Lamberton, C., \& Stephen A. T. (2016). A Thematic Exploration of Digital, Social Media, and Mobile Marketing: Research Evolution from 2000 to 2015 and an Agenda for Future Inquiry. Journal of Marketing, 80(6), 146-172. https://doi.org/10.1509/jm.15.0415

Ley, A., \& Weaven, S. (2011). Exploring agency dynamics of crowdfunding in start-up capital financing. Academy of Entrepreneurship Journal, 17(1), 85-110.

Löher, J. (2017). The interaction of equity crowdfunding platforms and ventures: an analysis of the preselection process. Venture Capital, 19(1-2), 51-74. https://doi.org/10.1080/13691066.2016.1252510

Lukkarinen, A., Teich, J. E., Wallenius, H., \& Wallenius, J. (2017). Success Drivers of Online Equity 
Crowdfunding Campaigns. Decision Support Systems, 87(C), 26-38. https://doi.org/10.1016/j.dss.2016.04.006

Macht, S. A., \& Weatherston, J. (2014). The Benefits of Online Crowdfunding for Fund-Seeking Business Ventures. Strategic Change, 23(1), 1-14. https://doi.org/10.1002/jsc.1955

Manchanda, K., \& Muralidharan, P. (2014). Crowdfunding: a new paradigm in start-up financing. Global Conference on Business and Finance Proceedings, 9(1), 369-374.

Manning, S., \& Bejarano, T. A. (2016). Convincing the crowd: Entrepreneurial storytelling in crowdfunding campaigns. Strategic Organization, 15(2), 194-219. https://doi.org/10.1177/1476127016648500

Mathews, S., \& Healy, M. (2008). From garage to global: the internet and international market growth, an SME perspective. International Journal of Internet Marketing and Advertising, 4(2), 179-196. https://doi.org/10.1504/IJIMA.2008.017021

McCarthy, E. J. (1960). Basic Marketing. A Managerial Approach. IL: Richard D. Irwin.

McCarthy, E. J. (1964). Basic Marketing. IL: Richard D. Irwin.

Merrilees, B., \& Fenech, T. (2007). From catalog to Web: B2B multi-channel marketing strategy. Industrial Marketing Management, 36(1), 44-49. https://doi.org/10.1016/j.indmarman.2006.06.014

Mochkabadi, K., \& Volkmann, C. K. (2018). Equity crowdfunding: a systematic review of the literature. Small Business Economics, 1-44. https://doi.org/10.1007/s11187-018-0081-x

Mokhtar, N. F. (2015). Internet Marketing Adoption by Small Business Enterprises in Malaysia. International Journal of Business and Social Science, 6(1), 59-65.

Möller, K. (2006). The Marketing Mix Revisited: Towards the 21st Century Marketing by E. Constantinides. Journal of Marketing Management, 22(3), 439-450. https://doi.org/10.1362/026725706776861181

Mollick, E. (2014). The dynamics of crowdfunding: An exploratory study. Journal of Business Venturing, 29(1), 1-16. https://doi.org/10.1016/j.jbusvent.2013.06.005

Mollick, E., \& Nanda, R. (2015). Wisdom or madness? Comparing crowds with expert evaluation in funding the arts. Management Science, 62(6), 1533-1553. https://doi.org/10.1287/mnsc.2015.2207

Osterwalder, A., \& Pigneur, Y. (2010). Business Model Generation: A Handbook for Visionaries, Game Changers, and Challengers. London: Wiley.

Politecnico of Milan (2018). $3^{\circ}$ Report italiano sul CrowdInvesting. Osservatori Entrepreneurship \& Finance

Politecnico of Milan (2019). $4^{\circ}$ Report italiano sul CrowdInvesting. Osservatori Entrepreneurship \& Finance.

Polzin, F., Toxopeus, H., \& Stam, E. (2018). The wisdom of the crowd in funding. Information heterogeneity and social networks of crowdfunders. Small Business Economics, 50(2), 251-273. https://doi.org/10.1007/s11187-016-9829-3

Popovic, D. (2006). Modelling the Marketing of High-Tech Start-Ups. Journal of Targeting, Measurement and Analysis for Marketing, 14(3), 260-276. https://doi.org/10.1057/palgrave.jt.5740186

Qiu, C. (2013). Issues in Crowdfunding: Theoretical and Empirical Investigation on Kickstarter. SSRN Electronic Journal. https://doi.org/10.2139/ssrn.2345872

Ralcheva, A., \& Roosenboom, P. (2016). On the Road to Success in Equity Crowdfunding. working paper. https://doi.org/10.2139/ssrn.2727742

Rochet, J. C., \& Tirole, J. (2006). Two-sided markets: a progress report. The RAND Journal of Economics, 35(3), 645-667. https://doi.org/10.1111/j.1756-2171.2006.tb00036.x

Rossi, A., \& Vismara, S. (2018). What do crowdfunding platforms do? A comparison between investment-based platforms in Europe. Eurasian Business Review, 8(1), 93-118. https://doi.org/10.1007/s40821-017-0092-6

Russel, C. A., \& Belch, M. (2005). A Managerial Investigation into the Product Placement Industry. Journal of Advertising Research, 45(1), 73-92. https://doi.org/10.1017/S0021849905050038

Ryu, S. (2018). Crowdfunding as a two-sided platform: Development of a Crowdfunding Participation Model. In Research Handbook of Finance and Sustainability. Cheltenham, UK: Edward Elgar Publishing. https://doi.org/10.4337/9781786432636.00039

Salomon, V. (2016). Emergent models of financial intermediation for innovative companies: from venture capital 
to crowdinvesting platforms in Switzerland. Venture Capital, 18(1), $21-41$. https://doi.org/10.1080/13691066.2015.1079953

Sayedi, A., \& Baghaie, M. (2017). Crowdfunding as a Marketing Tool. https://doi.org/10.2139/ssrn.2938183

Sharma, A., \& Sheth, J. (2004). Web-based Marketing: The Coming Revolution in Marketing Thought and Strategy. Journal of Business Research, 57(7), 696-702. https://doi.org/10.1016/S0148-2963(02)00350-8

Surowiecki, J. (2005). The wisdom of crowds. New York: Anchor Books.

Tamilia, R. D., Senecal, S., \& Corriveau, G. (2002). Conventional Channels of Distribution and Electronic Intermediaries. Journal of Marketing Channels, 9(3-4), 27-48. https://doi.org/10.1300/J049v09n03_03

Teo, T. S. H. (2005). Usage and effectiveness of online marketing tools among Business-to-Consumer (B2C) firms in Singapore. International Journal of Information Management, 25(3), $203-213$. https://doi.org/10.1016/j.ijinfomgt.2004.12.007

Tomczak, A., \& Brem, A. (2013). A Conceptualized Investment Model of Crowdfunding. Venture Capital, 15(4), 335-359. https://doi.org/10.1080/13691066.2013.847614

Troise, C. (2019). Entrepreneurship and Equity Crowdfunding: Does It Matter? International Journal of Business and Management, 14(10), 72-86. https://doi.org/10.5539/ijbm.v14n10p72

Vismara, S. (2016). Equity retention and social network theory in equity crowdfunding. Small Business Economics, 46(4), 579-590. https://doi.org/10.1007/s11187-016-9710-4

Vismara, S. (2018). Information Cascades Among Investors in Equity Crowdfunding. Entrepreneurship Theory and Practice, 42(3), 467-497. https://doi.org/10.1111/etap.12261

Vulkan, N., Åstebro, T. B., \& Sierra, M. F. (2016), Equity Crowdfunding: A New Phenomena. Journal of Business Venturing Insights, 5, 37-49. https://doi.org/10.1016/j.jbvi.2016.02.001

Wright, J. (2004). One-Sided Logic in Two-Sided Markets. Review of Network Economics, 3(1), 1-21. https://doi.org/10.2202/1446-9022.1042

Yamen, S., \& Goldfeder, Y. (2015). Equity Crowdfunding-A Wolf in Sheep's Clothing: The implications of crowdfunding legislation under the JOBS Act. Brigham Young University International Law \& Management Review, 11(1), 41-71. Retrieved from https://digitalcommons.law.byu.edu/ilmr/vol11/iss1/4

Yamin, M., \& Sinkovics, R. R. (2006). Online internationalisation, psychic distance reduction and the virtuality trap. International Business Review, 15(4), 339-360. https://doi.org/10.1016/j.ibusrev.2006.03.002

Zheng, H., Li, D., Wua, J., \& Xu, Y. (2014). The role of multidimensional social capital in crowdfunding: A comparative study in China and US. Information \& Management, 51(4), 488-496. https://doi.org/10.1016/j.im.2014.03.003

\section{Notes}

Note 1. Recently implemented and expanded with the D.L. n. 50 of 24/04/2017 and the Decreto Legge 3.0.

Note 2. Last year, the Equinvest platform merged with the company Backtowork24 Srl (Politecnico of Milan, 2018). This study considers the projects posted on the platform since its origin (2015). Since the platform launched a limited number of campaigns in previous years, at this stage the platform is considered as a SPs, however the recent numbers in terms of new initiatives (up to the first half of 2019) show a growth of the platform (Politecnico of Milan, 2019) that in future could be considered as a LPs.

\section{Copyrights}

Copyright for this article is retained by the author, with first publication rights granted to the journal.

This is an open-access article distributed under the terms and conditions of the Creative Commons Attribution license (http://creativecommons.org/licenses/by/4.0/). 